\title{
Empowerment Programs among Local Inhabitants at Rabak Residence in Indonesia
}

\author{
Roikhan Mochamad Aziz \\ Department of Master of Islamic Banking, Faculty of Economics and Business, UIN Syarif Hidayatullah, \\ Jakarta, Indonesia
}

Submitted: March 16 2018 ; Revised: November 29 ${ }^{\text {th }} 2020$; Accepted: January $07^{\text {th }} 2021$

$\begin{array}{ll}\text { Keywords: } & \text { Abstract Community service in Rabak Village, Bogor, Indonesia, was done for } \\ \text { Community } & 30 \text { days, involving } 16 \text { students from } 7 \text { faculties with an additional } 1 \text { lecturer as } \\ \text { service } & \text { a supervisor. Activities were conducted from August until September 2017. The } \\ \text { program } & \text { approach used the methodology of Hahslm with the ontology of Islam, } \\ \text { Hahslm } & \text { comprehensiveness in epistemology, and axiology of balancing. This guidance } \\ \text { Rabak } & \text { method utilized the straight path theory that combines the three main factors, } \\ \text { Reflexivity } & \text { internal, external, and reflexivities such as academicians, regulators, and ulama. } \\ & \text { For the planning and implementation, the research had objectives to map } \\ & \text { community potential, increase people capacity and transfer education. There } \\ & \text { were problems with local culture and obstacles encountered such as lack of } \\ & \text { time, sort of consolidating and coordinating with various parties in internal } \\ & \text { group members and supervisors, external parties such as sponsors, as well as } \\ & \text { the reflexivity of ulama and religious leaders. From the results of the activities, } \\ & \text { there were several successes: increasing community participation in } \\ \text { development programs in villages, increasing motivation to learners in } & \\ \text { elementary and junior high school to continue education to higher levels, and } & \text { to educate public knowledge about Islamic universities, to increase public } \\ \text { awareness of the importance of marriage books, and increase physical building } & \\ & \text { or development rehabilitation of water reservoirs, and reading parks. }\end{array}$

\section{INTRODUCTION}

\subsection{Background}

Every human being must have a dream and a purpose in life. If students do not have a dream and the purpose of life, then those persons will be confused about which direction should be anchored. So, humans need guidance to be able to live with balance (Aziz, 2017). Every aspiration which is stored must have different passions. The ideal that can be achieved is through diligent study and earnestness. The place for study can be through the school. There are so many schools in the remote villages that have few teachers. To realize every child's dream, many teachers need to be able to read and write. Importantly, being a part of the ideals and the dreams of the younger generation in rural education is the solution.

Indeed, students can help the local community by empowering the dynivity to catalyze the relation among internal, external, and reflexivity of a regency (Aziz, 2018). University can bring motivation, enthusiasm to learn, embrace every child, to try everyone realize the ideals and dreams. It is a form of devotion, in fact, to the millennial generation. Selfless and willing to take the time just to be able to educate the nation's children.

Students from an Islamic university must have a high level of social sensitivity. Help each other in a community and provide knowledge to be shared to

ISSN 2460-9447 (print), ISSN 2541-5883 (online)

${ }^{*}$ Corresponding author : Roikhan Mochamad Aziz

Master of Islamic Banking Department, Faculty of Economics and Business, UIN Syarif Hidayatullah, Jalan Juanda No 95, Ciputat, Tangerang, Banten 15412, Indonesia

Email: roikhan.aziz@uinjkt.ac.id 
remote/rural areas such as Rabak Village, Rumpin Subdistrict, Bogor Regency as a place of community service because the Rabak Village has many limitations regarding current updates in science, technology, and religiosity. Starting from education, facilities, and infrastructure in the village, the fact those infrastructure and access roads to the village still have in a bad condition. Facilities located in the village have many shortcomings in structures. These reasons were triggered community development from State Islamic University (UIN Jakarta) as KKN (Kuliah Kerja Nyata $=$ Student Service Learning) 3R (Reflexivity Religiosity Rabak) eager to help and serve for empowerment in Rabak Village, Rumpin District, Bogor Regency as community facilitator.

\subsection{General description in Rabak Village}

Rabak Village is a village in District Rumpin at Bogor Regency in Indonesia. This village is the largest in Rumpin District with an area of $\pm 155,550$ ha. Rabak Village is divided into 4 hamlets (dusun) with 6 Rukun Warga (RW), 43 Rukun Tetangga (RT). The first hamlet consists of 2 RW's and 19 RT's. Second hamlet consists of 1 RW's and 9 RT's. Third hamlet consists of 1 RW's and 6 RT's. Fourth hamlet consists of 2 RW's and 9 RT's.

Rabak Village is bordered by Gobang Village in the South, Cibodas Village in the East, Banyu Asih Village in the West, Kampung Sawah Village in the North, in Rumpin District. The majority of people in Rabak Village are Muslims. This condition is also supported by facilities and infrastructures of worship and reflexivities, there are 23 mushallas, 15 mosques, and 27 majlis ta'lim (Islamic community study), and 12 pondok pesantren (elementary Islamic boarding school).

The level of education, in this village of Rabak, follows the national education scheme with the 9-year compulsory school as predominanted by elementary school graduates that consists of 2499 students, and junior high school graduates consist of 1024 students. Meanwhile, high school graduates consist of 462 students. Academy graduates consist of 37 students and universities consist of 29 students (Nugraha, 2016). Infrastructure in Rabak Village had been disrupted by environmental conditions and was in bad condition. This bad condition can be seen in front of Pemda office that across Rabak Village.

\section{METHOD}

\subsection{Focus and priority program}

After the result of problem identification, the KKN 3R Team prioritized programs and activities to help the community at least reduce or minimize the problems in Rabak Village. In conducting KKN activities, the KKN team has made several activities based on the conditions occurring in Rabak Village and accordance with the potential of KKN 3R members. The programs as a form of service and community empowerment that the KKN Team provide:

\section{Table 1. Priority and program activities}

Focus Problem

Priority and Activity Program

Spirit of Rabak Teaching Educational Unit and Hahslm 1 . Hahslm Education Service Activities at SDN 01 Rabak
Theory Hahslm

2. Education Service Activities of Hahslm in SDN Sampay Hahslm Approach

3. Education Service Activities of Hahslm in PAUD Rizky Scholar Hahslm Method

4. Education Service Activities of Hahslm in PAUD Pertiwi Hahslm Methodology

5. Guidance Read the Qur'an and Hahslm

6. Tutoring KKN 3R 2017 Theory of Hahslm

7. Love Movement Activities in Cooperation with other university students 
8. Intelligent Consumer Extension Activities In collaboration with other university students

9. Climate Student Forum Activities (Introduction to Weather) In collaboration with other university students

10. Education Service Activities Language Hahslm

Rabak Fond of Reading

1. Reading Park By KKN 3R

Rabak Illiteracy

1. Activity of Education Service of Non-Literacy

Economic Unit

Creative Economic

1. Economic Counseling by Rakan Indonesia

2. Handicraft Training From Copper

Infrastructure Unit

3R Membangun

1. Construction of MCK

2. Mini Library

Sosial Unit

3R Care Centre

1. Commemoration of HUT RI

2. Isbat Nikah Counseling

3. Helping to Build Citizens Homes

Health Unit

Health Unit at Rabak

1. Free Doctor

2. Dental health education

Source: Analysis, 2017

\subsection{Goals and targets}

In running the programs that KKN Team has made for the village of Rabak, it is necessary to have a thought in determining what goals and targets to be achieved, here is the elaboration:

Table 2. Goals and targets

\begin{tabular}{|c|c|c|c|}
\hline No. & Activities & Goals & Targets \\
\hline 1 & Teaching at SDN 01 Rabak & $\begin{array}{l}\text { Teacher SDN } \\
01 \text { Rabak }\end{array}$ & 6 teachers assisted in teaching students. \\
\hline 2 & $\begin{array}{l}\text { Teaching at SDN } 01 \\
\text { Sampay }\end{array}$ & $\begin{array}{l}\text { Teacher SDN } \\
\text { Sampay }\end{array}$ & 5 teachers assisted in teaching students \\
\hline 3 & $\begin{array}{l}\text { Teaching at PAUD Rizky } \\
\text { Cendikia }\end{array}$ & $\begin{array}{l}\text { Teacher PAUD } \\
\text { Pertiwi }\end{array}$ & $\begin{array}{l}3 \text { teachers assisted in teaching and learning activities } \\
\text { in PAUD Rizky Cendikia. }\end{array}$ \\
\hline 4 & Teaching at PAUD Pertiwi & $\begin{array}{l}\text { Teacher PAUD } \\
\text { Pertiwi }\end{array}$ & $\begin{array}{l}2 \text { teachers assisted in teaching and learning activities } \\
\text { in Early Childhood Education }\end{array}$ \\
\hline 5 & $\begin{array}{l}\text { Reading Guidance of the } \\
\text { Qur'an }\end{array}$ & $\begin{array}{l}\text { Children RW } \\
\text { 03 Village } \\
\text { Rabak }\end{array}$ & 3 siblings get material about tajwid. \\
\hline 6 & Tutoring & $\begin{array}{l}\text { Children RW } \\
03 \text { Village } \\
\text { Rabak }\end{array}$ & $\begin{array}{l}25 \text { younger siblings get additional material in } \\
\text { Mathematics, Biology, Physics, and Religion. }\end{array}$ \\
\hline
\end{tabular}


$7 \quad$ Arabic and English Class

$8 \quad$ Rabak Fond of Reading

9 Rabak Illiteracy

10 Economic Counseling

12

Creative Economy

Making MCK

13

Commemoration of HUT

14

Isbat Nikah Counseling

15

16

Helping the Development

of Citizens' Homes

Free treatment

17 Dental Health Education

Movement of Love of

18

Farmers

Indonesia Climate Student

19 Forum (Weather

Introduction)

$20 \quad$ Training

21
Children RW

03 Village

Rabak

Children RW

03 Village

Rabak

Women Village

Rabak

Women Village

Rabak RW 03

Women Rabak

Villagers

Rabak RW 01

Children RW

03 Desa Rabak

Villagers

Rabak RW 03

Villagers

Rabak RW 04

Villagers

Rabak RW 03

Villagers

Rabak

Students SDN

Sampay

Students SDN

01 Rabak

Students SDN

01 Rabak

Students SDN

Sampay
15 younger siblings of Lebak Salak village of Rabak RW 03 village get additional English and Arabic material lessons.

60 younger siblings get reading book facilities.

10 mothers of Kp. Lebak Salak Helped in learning to read, write, and count.

10 mothers of Kp. Lebak Salak Helped in learning to read, write, and count.

Villagers of RabakRW 01/06 Kp. Dukuh Malang get facilities for MCK

40 siblings of Rabak Village Kp. Lebak Salak

received a reading book at the post of KKN 3R.

100 villagers Rabak assisted in the celebration of the 72nd anniversary of RI.

100 villagers of Rabak get information about Marriage Book.

20 villagers of Rabak get power.

120 villagers from Rabak get free medical treatment.

80 students get information about the cessation of health for the teeth.

40 students of SDN 01 Rabak get knowledge about agriculture

40 students of SDN 01 Rabak get knowledge about the weather.

40 students of SDN 01 Rabak get knowledge about the weather.

60 Brothers and sisters get information on healthy and nutritious food

\section{RESULT AND DISCUSSION}

\subsection{Social mapping}

In Rabak Village, Rumpin District, Bogor Regency. This village is very abundant in terms of its nature. However, in terms of economy, Rabak Village is still difficult in developing business. Rabak Village has begun to show its economic development although the stage is very slow but began to grow slightly.

From a religious point of view, the village of Rabak is a fairly religious village where residents here still apply the religious system from generation to generation as well as aspects (anti-speakers) that residents do not use speakers in any religious activity. In terms of education Hahslm, the absence of junior high school in the village of Rabak made the children struggle to go to faraway state schools. Facilities in schools still have many shortcomings, ranging from bathrooms in schools that are not so comfortable, lack of laboratory practice at school, and so forth. In terms of health is also still lacking because there is only Puskesmas Pembantu (branch of the health community 
center) that open on Tuesday and KKN teams. But in terms of security, Rabak Village can be practically quite safe with existing Siskamling activities.

Rabak people want the schools in Rabak to become like the ones in the capital. Though the Rabak Village is a village that is quite close to the capital of Jakarta, with only 45 minutes. In Jakarta everything is easy, but the people who live in the suburbs are still fairly difficult. Residents want the countryside to be like the Capital of Jakarta, where everything is easily accessible and needs can be met. To be able to realize this Dream Village, every citizen must be aware of each other's needs. Everyone is born with different advantages. It all depends on self-awareness whether or not to develop the ability. In this village of Rabak the advantages are in terms of nature, especially bananas, and the shortcomings are in economic terms. The population should be able to develop the advantages. The KKN Team tries to help out what it lacks. Because of society's difficulties in terms of marketing and so on. The team also motivates every citizen to try and develop what has been cultivated. It will also be one way to realize the Dream Village.

In the Rabak Village, there is Lebak Salak village right in RW 03. There is the highly respected Abah Amsah, there is Mr. Mamat as chairman of RW 03, Mr. Suherman as Head of Rabak who also lived in RW 03, and also there is Mr. Iwan, the teacher from SDN 01 Rabak. They are the influential people in Kampung Lebak Salak, who were asked and became the elders in the village. In RW 03, pengajian are often held for the men, usually once a week at the residence of Abah Amsah. Recitation for the women are held every Wednesday at a local mosque.

\subsection{Social intervention methods}

Social intervention methods can be interpreted as a way or strategy in assisting the community (individuals, groups, and communities) to improve the welfare of a person through the re-functioning of social functions. The point is that every society should be able to play a role in society, in which status must be acknowledged by the environment and the status does not exceed the limits of the norm. In this case, social intervention is intended to provide planned change to individuals, groups, and communities. It is said 'planned changes' so that later efforts can be given assistance in the evaluation and measured its success. In the intervention mentioned there are at least two parties, namely (1) people, groups, families, or community who are in a powerless condition; and (2) those who are capable of helping to relieve or eliminate suffering, or who can restore the empowerment of the community as they are or can help to improve their standard of living. Persons subject to such interventions with clients and intervening parties are called interveners. Through the client's social intervention, there will be a change in direction towards improvement and progress or positive change. Actions aimed at helping individuals or groups or families or communities within the social life context of a society are called social interventions, which Johnson is expresses as:

1. Specific actions, carried out by an intervening agent, are associated with attempts to bring about change.

2. A tool used by the interventionist to solve problems rationally.

The use of the word 'social intervention' rather than 'intervention' aims to highlight two considerations: First, individuals are part of the social system so that although the main aid method is individual psychological therapy, the social environment needs to be given intervention. Second, social intervention refers to the area of intervention and objectives, in which the goal of social intervention is to improve the social function of the target group of change, the social function is said to have been achieved if the distance between expectations and reality is not too far away. In other words, the social intervention aims to minimize the distance and even align the environmental expectations with the real conditions.

\subsection{Hahslm's Approach to community empowerment}

The Hahslm Approach is a genuine current methodology of Islamic value that gives guidance on how to walk the community straight to God to worship, in this case, worship in the context of community empowerment (Aziz, 2017).

In Theory of Hahslm or abbreviated Theory H, there is a specificity that is the element of worship in the framework of community empowerment. The meaning of this worship comes from radial variables in the formula $\mathrm{H}$, where radial means a circular variable or radiation in all directions. Later in the lateral language, the radial vocabulary is interpreted as a word of worship in the great theoretical flow. This word of worship can be interpreted as community empowerment in KKN activity. Empowerment in this discussion is an element, factor, or variable. Meanwhile, according to the term, empowerment is a variable that is intangible, or variables that can not be assessed empirically. Understanding of worship, according to the researcher, is a measure, to measure the intangible asset variable, which is not studied, in the realm of linear science, by closer to Islamic values, or what is contained in the Qur'an, or Hadith or Fatwafatwa companions, who become weighted supporters. 


\section{Islam Kâffah}

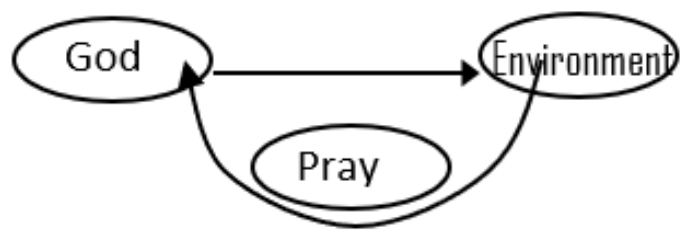

Figure 1. Diagram of kaffah thinking in Islam (Aziz, 2017)

The picture of kaffah in Islam above means that a comprehensive system must be worth of Islam, so a kaffah system will consist of 3 main parts: God, Environment, and Prayer. These three variables will be metamorphosed according to the context of the topic being focused on. But the rationale of an intact system or sub-system must consist of 3 things. The H Theory approach can be developed in life such as the development of economic institutions. By transforming God's first element into a macroeconomic element, then the second element in nature that can be converted into microeconomic elements, and its feedback is transformed worship into an economic opportunity.

Calibrated empowerment in the value of worship can be calculated, like any other data, or in an absolute value. Example: $\mathrm{X} 1$ has a larger value, than $\mathrm{X} 2$, if $\mathrm{X} 1$ is 1 then $\mathrm{X} 2$ is 2 , etc. This weight is a correction, to the empirical approach (eg, econometric model). During this empirical approach, just processing the numbers, or tangible variables only. The empirical approach can only interpret the numbers, which are visible. Though a lot of variable are intangible variables, which may be the cause as well as the solution to a problem.

Weights that are the result of the test, based on the expert ratio or common knowledge, to include the intangible value, which is not covered by the existing analysis tools. By entering the weight value, as a result of the test, makes the analytical tool, better than the analytical tool, which relies solely on variable items, from tabulation data. The results of this weighting test can reflect the value of Islam, by including variables, which are relative, abstract, or contain the meaning of worship, ethics, morals, greatness, or other intangible value. In this case, weights can arise, from the subjectivity of the researcher (eg subjective well-being: happiness) or non-empirical data, or range value or intuitive value, or sensitivity analysis based on common acceptance, i.e. placing quantities, one thing bigger than another, because the contribution or influence or multiplier effect. According to worship formulation that written in Quran (QS 15:87):

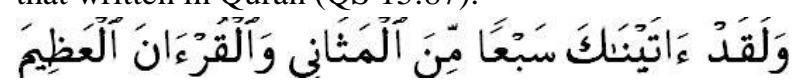

Meaning: "And verily we have given unto you, seven verses that are recited over and over, and the great Quran”.
The above verse, explaining that Allah, has sent down to man, seven verses that are read over and over again. The meaning of the seven verses, which are read over and over again, is the letter of Al-Faatihah, which consists of seven verses. Some commentators, saying these seven verses, are seven long letters, namely AlBaqarah, Ali Imran, Al-Maaidah, An-Nissa', Al' Araaf, Al An'aam, and Al-Anfaal.

According to Aziz (2015) of the verse, got two main variables, namely 7 (Seven) and Al-Qur'an. Seven (7) is considered an absolute variable, and the Qur'an can still be broken down into 2,3,1,9. If multiplied, the $2 \times 3 \times 19$ result is 114 .

So we get five numbers, that is $7,2,3,1,9$. To make it easy to create formulas, the numbers are changed, into letters. In the above table, it can be seen 7 being $\mathrm{A}$ (Alif), 2 being h (hanif), 3 being $\mathrm{S}$ (Sin/Human), 1 being L (Lam/Lillah), and 9 being M (Mim/Masjid). So AhSLM is formed. To make it an equation, a dependent variable is required. The variable is $H$ (Huda/instructions). Huda is derived from number 4. The number 4 , comes from the sum of $7+2+3+1+$ $9=22$, which becomes $2+2=4$. Finally, formed the equation $\mathrm{H}=\mathrm{Ah}(\mathrm{S}, \mathrm{L}, \mathrm{M})$. When analyzed in everyday life, A reflects the relationship with the community, $\mathrm{h}$ reflects the relationship with fellow human beings, $\mathrm{S}$ reflects the relationship with oneself, $\mathrm{L}$ reflects the relationship with the environment, and $\mathrm{M}$ reflects the ethical relationship. This $\mathrm{M}$ variable is hard to find, in life. If analogous to an econometric regression test, A reflects the simultaneous test or $\mathrm{F}$. h test is analogous to a positive or negative significance test, $\mathrm{S}$ as a partial test or t-test, $\mathrm{L}$ as the coefficient of determination or R2. Meanwhile, for variable $\mathrm{M}$, there is no equivalent to analogy. This is because $M$ is an intangible asset, which can not be calculated in econometrics. Therefore, to overcome this, we need to weight the model to make the results more perfect. Including the value of worship as a factor of community empowerment, the definition of worship here does not mean the average or the value of assets, but rather the empowerment of the community to see the gap between the expected results with real conditions, so there is the justification that sometimes the Islamic value approach has a difference with real conditions in the field.

Philosophically, the formulation of worship, in the formula of Hahslm has a foundation of thought, namely:

a) Ontology in this economic concept is always based on the value of Islam. Concerning the Quran Surah Ali Imron [3]: paragraph 19, which states that any existing system, whether economic system, management system, accounting system, or even the Islamic economic system itself, or sharia banking system, must refer to the concept of Islam. "That in fact, the system created by Allah is Islam". 


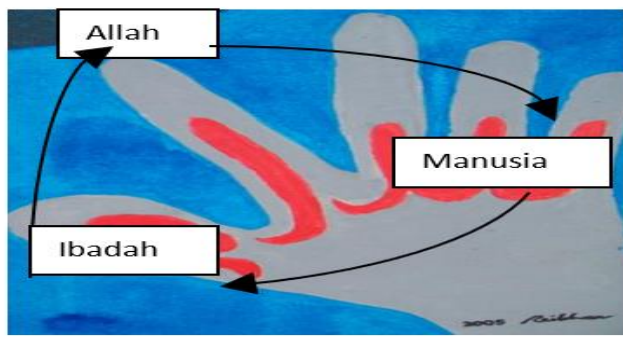

Figure 2. The basic model of hahslm approach chart (Aziz, 2009)

b) Epistemologically, the concept has a magnitude that is thorough, because it takes the point of view from the great first and always referrs to the Quranic verses. The magnitude of this concept, referring to the Quran (QS 2:208), which states that a good system is a comprehensive whole and there must be Islamic value in it. For entering the existence of God, and the ultimate value given is worship. So the main factor which is thorough consists of 3 things: man, God, worship.

c) The axiom in this concept also refers to the verses of the Quran which explain that there are dual functions in this life, such as darkness and light, positive and negative, good and bad. So easily understood axiologically, this concept following the Quran of Surat Yasin [36]: 36 as above which says that God created nature in pairs.

Based on this, the approach undertaken in community empowerment in our location was a problem-solving approach. The approach of planning and implementing Community Service Program-PPM program based on problem solving approach is one of the efforts to make a social change to the society by looking at the problem which is in the community. Along the way, we collected every problem in the community before implementing programs and activities. Here are some steps for troubleshooting to succeed, as follows:

1. Identify a problem.

2. Mobilizing resources as necessary.

3. Plan the program by the existing natural resources.

4. Find troubleshooting.

5. Program planning with its evaluation.

Community empowerment is a thing that has a clear purpose and achievable with a clear outcome. Therefore, the empowerment of society is very important with the spirit of work strategy to achieve a goal. In everyday life, the strategy is often called a step to achieve a goal. Strategies are often interpreted with a variety of approaches:
a. Strategy as a plan.
b. Strategy as an activity.
c. Strategy as an instrument.
d. Strategy as a system.
e. Strategy as a mindset.

From the strategy mentioned above, that strategy is a step in a plan to achieve a goal, including community empowerment.

\subsection{Results of achievement factors}

There are several driving factors which become a success a program activity which we have implemented:

1. The solidarity and teamwork of $3 \mathrm{R} 144$ which is very good. Because each member was aware of their responsibilities, the programs went well.

2. The Rabak Village community was very enthusiastic with several programs from 3R 144.

3. Children and youth were also very excited to learn together at $3 \mathrm{R}$ post.

4. Full support from local leaders of the RT and RW.

5. Evaluation from each $3 \mathrm{R}$ program to improve future events and plans.

The inhibiting factors from the planned activities were:

1. The procurement of birth certificates could not be executed, due to regulatory changes from the Civil Registry Service and Occupation which decrees that the citizens must come to the office. This became one of the obstacles in obtaining the birth certificate of children because the office was located far away from the where the people lived.

2. The celebration of the national independence day was not done in another RW because of the distance constraint. The celebration was only focused to RW 03 in Kampung Lebak Salak.

Another limiting factor for the KKN 3R team was due to the traditions and culture. Implementation of theories for this limitation is to explain to society that in theory, an advanced society is a community that can accept changes from outside. The obstacles are the parents find it difficult to adapt while young ones are willing to adapt.

\section{CONCLUSION}

The Community Service Program organized by PPM UIN Syarif Hidayatullah Jakarta 2017 is one of the activities that facilitate students to serve the community. Reflexivity Embracing Rabak (3R) has conducted a Community Service Program in Rabak Village, Rumpin District, Bogor Regency. Devotion to society is evidenced by action and concrete evidence that has been obtained by students during college. Each student served and gave the knowledge that they owned. The problems which exist in Rabak Village have been accommodated and given the best solutions, starting from teaching and learning activities in posts, teaching in elementary and early childhood. Many people there were affected by skin diseases, so the $3 R$ team held free treatment from TAKAFUL. There are 
several aspects which are the reasons for lack of economic development in Rabak Village due to their lack of understanding about how to market a product. Therefore, 3R team created activities on creative economy from Rakan Indonesia. The mothers and parents joined the event, to improved their knowledge and insight. Unavailability of reading books caused low reading interest in children. Therefore, the solution of

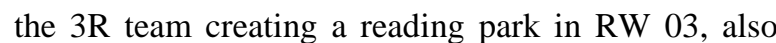
makes one of the physical evidence of the activities of the $3 \mathrm{R}$ team.

\section{REFERENCES}

Aziz, RM. (2009). Education on Root Of Islam. Proceeding, International Seminar On Islamic Education. UNJ, Jakarta.

Aziz, RM. (2010). New Paradigm in On Sinlammim Kaffah In Islamic Economics. Jurnal Signifikan. 9(2), 139-148.

Aziz, RM. (2012). New Paradigm on Islamic Kafah in Islamic Economics. Jurnal Signifikan. 1(2), 139148.

Aziz, RM. (2014). Integrasi Ilmu Ekonomi Islam: Pendekatan Filosofis dan Simbolik. Integrasi Keilmuan. UIN Press, Jakarta.

Aziz, RM. (2015). Hahslm Islamic Economic Methodology. Proceeding ICOSEC: Developing Countries Readiness Toward Global Universitas Negri Solo, Surakarta.

Aziz, RM. (2016). Teori H Sebagai Wahyu Dan Turats Dalam Islam. Jurnal Ushuluddin. 24(1), 103112.

Aziz, RM. (2018). Islam Dan Pengetahuan. Salemba Diniyah, Jakarta.

Hardjomarsono, Boediman. (2014). Teori dan Metode Intervensi sosial. Tangerang Selatan: Universitas Terbuka

Mardikanto, Totok. (2014). Pemberdayaan Masyarakat dalam Perspektif Kebijakan Publik. Bandung: Penerbit Alfabeta.

Nugraha, Murojab. (2016). Rabak: Rajutan Asa di Pinggir Kota. Ciputat: Pusat Pengabdian kepada Masyarakat, UIN Syarif Hidayatullah Jakarta.

Nurul Ulfah, Qurrotul'ain. (2016). Selayang Pandang Kampung Baru Asih . Ciputat: Pusat Pengabdian kepada Masyarakat, UIN Syarif Hidayatullah Jakarta.

Nugraha, Eva. (2017). Panduan Penyusunan Buku Laporan Hasil KKN-PPM 2017. Ciputat: Pusat Pengabdian kepada Masyarakat.

Peta "Rabak, Rumpin Bogor" diakses pada 5 September 2017 dari: https://://maps.google.com/maps?saddr=(6.3079 129\%2C106.7518006)

Rencana Pembangunan Jangka Menengah Desa (RPJM Desa) Desa Rabak Kecamatan Rumpin tahun 2014-2019, Dokumen tidak dipublikasikan. 